\title{
A SIMPLE AND RAPID METHOD FOR COLLECTING SALIVA TO ASSESS SODIUM STATUS IN SHEEP
}

\author{
UM MÉTODO SIMPLES E RÁPIDO DE COLHEITA DE SALIVA \\ PARA AVALIAR ESTADOS NORMAIS OU DEFICIENTES DE SÓDIO, EM OVINOS
}

\author{
Enrico Lippi Ortolani ${ }^{1}$
}

\section{SUMMARY}

Fifteen lambs were fed diet with normal $(0.11 \%)$ or deficient levels of sodium ( $0.035 \%)$, respectively, for five weeks on each diet. At the end of each period saliva was collected by three different methods: swabbing with a $5 \times 5 \times 1.25 \mathrm{~cm}$ synthetic sponge, aspiration with a $15 \mathrm{~cm}$ long plastic tube connected to a $20 \mathrm{ml}$ syringe and sucking with a $4 \mathrm{~mm} \times 45 \mathrm{~cm}$ long plastic tube through a water-jet aspirator pump or an eletric motor pump. The volume of saliva collected/min and the salivary sodium:potassium ratio were analysed. Larger volume of saliva was obtained with the developed sucking apparatus than with the sponge or the syringe. There was no influence of the method of saliva collection on the values of salivary Na:K ratio in both periods. Nevertheless, the lower the sodium dietary level was, the smaller the salivary Na:K ratio. Five weeks of low sodium diet intake resulted in a decrease in the salivary Na:K ratio values by half. However, the lambs did not exhibit any clinical sign of sodium deficiency. The advantages of the developed method to collect saliva are discussed.

Key words: saliva, collection, methods, sheep, salivary sodium:potassium ratio.

RESUMO

Neste experimento foram utilizados 15 cordeiros os quais receberam dietas com níveis adequados de sódio $(0,11 \%)$ ou deficientes deste elemento $(0,035 \%)$, respectivamente, por dois períodos de cinco semanas cada. Ao término de cada período, foram colhidas amostras de saliva, de todos animais, por três diferentes métodos: absorção com o uso de uma esponja sintética com as seguintes medidas $5 \times 5 \times 1,25 \mathrm{~cm}$; aspiração com um tubo plástico de $15 \mathrm{~cm}$ de comprimento conectado a uma seringa de 20ml; e através de sucção por tubo plástico, com $4 \mathrm{~mm} x$ $45 \mathrm{~cm}$ de comprimento, ligado a uma trompa de vácuo conectada a uma torneira ou a uma bomba motora elétrica geradora de vácuo. Foram avaliados o volume de saliva colhida por minuto e a razão das concentrações de sódio:potásio salivar. Quantidades muito maiores de saliva $(p<0,001)$ foram colhidas através do método utilizando trompa ou bomba motora de vácuo que com o auxílio de esponja ou de seringa. Não existiu diferença entre a razão das concentrações Na:K salivar nas amostras colhidas pelos três diferentes métodos, nos períodos experimentais. A ingestão de uma dieta pobre em sódio, pelos ovinos, provocou uma queda, de cerca de 50\%, nos valores da razão Na:K salivar, comparado com os valores encontrados na dieta normosódica. Porém, os animais submetidos a dieta carente em sódio não apresentaram quaisquer sinais clínicos sugestivos de deficiência deste elemento. As vantagens do método desenvolvido para colheita de saliva são apresentadas e discutidas.

Palavras-chave: saliva, colheita, métodos, ovinos, razão sódio:potássio salivar.

\section{INTRODUCTION}

Most of the tropical and semi-tropical grasses are very poor in sodium (MORRIS, 1980). Analyses of several pastures species from extensive areas where ruminants are raised in Brazil showed that sodium levels can be extremely poor (ANDREASI $\boldsymbol{e} t$ al., 1966/67; PRADA, 1985; SOUZA et al., 1982; CAVALHEIRO \& TRINDADE, 1992). A survey

${ }^{1}$ Médico Veterinário, MsC, PhD, Professor, Departamento de Clínica Médica da Faculdade de Medicina Veterinária e Zootecnia, Universidade de São Paulo. Av. Prof. Dr. Orlando Marques de Paiva, nº 87, Cidade Universitária, 05508-900, São Paulo, SP, Brazil. FAX 055-11$818-4228$. 
carried out by ORTOLANI (1993) verified that 32 $(13.33 \%)$ out of 240 beef cattle range farms in wide areas from Brazil and Paraguay do not supplement the herds with commom salt. Besides lack of supplementation sodium deficiency can arise in sheep with mixed gastrointestinal parasitism through increasing excretion of sodium in the feaces (OOSTERHUIS, 1991).

According to MORRIS (1980) salivary Na: $\mathrm{K}$ ratio is regarded as the most practical and realible indicator of sodium status in ruminants. Low levels of dietary sodium for a relatively short period evoke an effective aldosterone production and liberation from adrenal cortex. This hormone acts on renal tubules and salivary glands in order to keep the homeostasis of sodium through an increased rate of potassium secretion and sodium reabsorption. Thus, ruminants with sodium deficiency have a narrow salivary $\mathrm{Na}: \mathrm{K}$ ratio.

Some techniques have been described to collect saliva in ruminants. The swabbing technique uses a synthetic sponge inserted into the mouth to be chewed by the animal in order to soak the sponge with saliva (DOBSON et al., 1960). A suction device for collecting saliva was adapted by MURPHY \& MURPHY (1970). The apparatus consisted of a stainless steel tubing connected to a rubber pipette filter that generated the vacuum for sucking. According to HOEGGEL (1990), this technique proved to be unsatisfactory to collect enough saliva. OOSTERHUIS (1991) collected sheep's saliva by sucking it with a $10-15 \mathrm{~cm}$ long plastic tube connected to a $20 \mathrm{ml}$ syringe.

However, under field conditions a simple, practical and rapid method for collecting saliva is still required. Moreover, the saliva sample collected must be representative of the current sodium status. The purpose of this study was to compare the efficiency of three different methods to collect saliva: swabbing, suction by a syringe and a suction device developed by the author. The volume of saliva collect per unit of time and salivary $\mathrm{Na}: \mathrm{K}$ ratio were analysed.

\section{MATERIALS AND METHODS}

Fifteen 9-months-old Suffolk x Greyface lambs were used. The lambs were kept in metabolic cages and were given in the first period, of five weeks, a whole barley grain diet containing $0.11 \%$ of $\mathrm{Na}$ in the DM. To one kilogram of whole barley grain was added $20 \mathrm{ml}$ of water, sugar $(12.8 \mathrm{~g} / \mathrm{kg})$, urea $(23.0 \mathrm{~g} /$ $\mathrm{kg})$, sodium chloride $(1,9 \mathrm{~g} / \mathrm{kg})$, calcium carbonate
$(12.5 \mathrm{~g} / \mathrm{kg})$ and a trace elements \& vitamins supplement (iron, zinc, iodine, cobalt, manganese, vitamins A, D and E) and were mixed for two hours. During this time all nutrients in water solution soaked the whole barley grain and migrated to its core. More details about the process and the diet composition were described by FIELD et al. (1988). In a second trial the animals were fed, for five weeks, the same diet but not supplemented with sodium chloride, corresponding to a deficient level of sodium $(0.035 \%)$. After complete adaptation to each diet saliva was collected from the lambs by three different methods: swabbing, sucking with a syringe and sucking with vacuum pump. For the swabbing collection the technique described by DOBSON et al. (1960) was adopted. A synthetic sponge measuring $5 \times 5 \times 1.25 \mathrm{~cm}$ which had previously been boiled three times in distilled water and dried was used. The sponge was held by forceps and rubbed up and down in the cheeks and over the tongue. Saliva was also obtained by aspiration with a $15 \mathrm{~cm}$ long plastic tube connected to a $20 \mathrm{ml}$ syringe (OOSTERHUIS, 1991).

The remaining method allowed to collect saliva by aspiration through a plastic tube of $4 \mathrm{~mm}$ of diameter $x 45 \mathrm{~cm}$ in lenght inserted in the mouth between the cheek and the molar teeth. This tube was fitted in a rubber stopper which was tightly inserted on a borosilicate glass $(50 \mathrm{ml})$ previously deionized with hidrochloridric acid $(0.1 \mathrm{~N})$ solution. Another plastic tube connected with the vacuum pump apparatus was inserted into a second orifice on the rubber stop. (Figure 1). Vacuum was generated by two different ways: a water-jet aspirator pump connected to a tap or an electric motor pump. In both cases the vacuum produced was enough to suck saliva fifty meters away from the apparatus. After one sampling, the collector tube was cleaned to remove the remainaing saliva with a flush of ion-free water using vacuum to aspirate the washing. A metal gag was used to keep the sheep's mouth opened during sampling in all methods.

The experiment was carried out in a $3 \times 3$ latin square design (three groups of five sheep each $\mathrm{x}$ three methods of saliva collection). Twenty four hours interval between collection for each method, within each feeding group, was adopted. The same squeme of sampling was repeated five weeks later with the remaining diet. To evaluate the efficiency collection of the different methods, it was stipulated that every sampling would last one minute per animal. The volume of saliva collected during this time was measured. When the amount of saliva was not enough (less than $1.5 \mathrm{ml}$ ) more saliva was collected using the same method until the required volume was reached. 


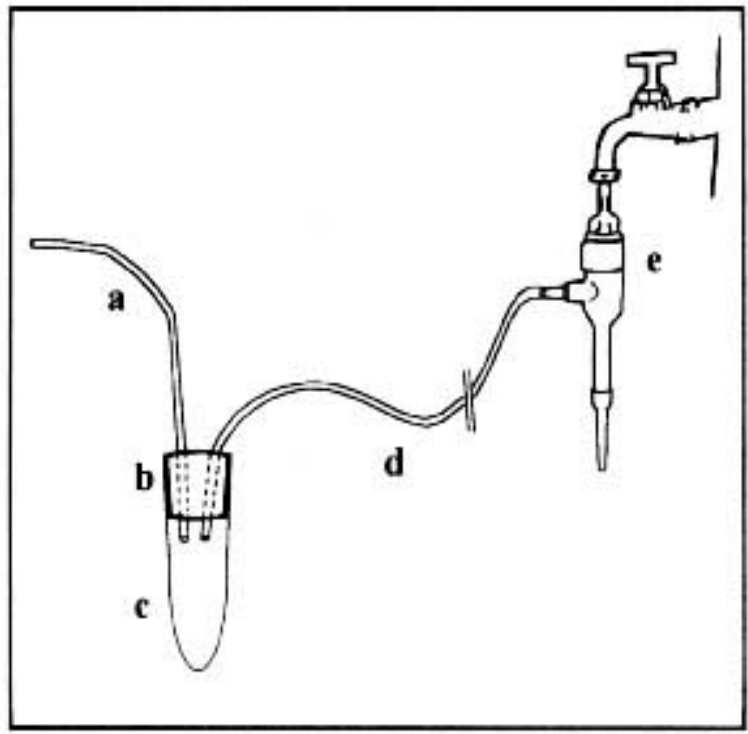

Figure 1-Diagram of the developed apparatus for collecting saliva from sheep. $a=$ aspiration tube $(4 \mathrm{~mm}$ diameter, $45 \mathrm{~cm}$ long); $\mathrm{b}=$ rubber stop; $\mathrm{c}=$ borosilicate glass; $\mathrm{d}=$ aspiration tube connected to the vacuum source (same diameter as tube a, up to $50 \mathrm{~m}$ long): $\mathrm{e}=$ water-jet aspirator pump connected to a tap.

Samples were placed in $1.5 \mathrm{ml}$ microcentrifugal eppendorf tubes and centrifuged at 13.000rev/min. Supernatants were analysed for $\mathrm{Na}$ and $\mathrm{K}$ in an IL Monarch 2.000 microcentrifugal analyser by ion-selective electrodes.

Differences between and within treatments were compared by analysis of variance with application of the least significant difference test. (SNEDCOR \& COCHRAN, 1967).

\section{DISCUSSION}

The sucking of saliva through vacuum pump presented some advantages compared with other two methods of collection. The volume of saliva collected per unit of time was greater in the former method (Table 1). Collection of saliva with vacuum pump was twice faster than other two methods. The handling of the plastic tube apparatus used to suck in this method was practical principally in reaching the region between the cheek and molar teeth where most of the secreted saliva stays before swallowing. Besides, the system used to flush deionized water to clean the contaminated plastic tube proved to be very efficient and did not produce any alteration on salivary $\mathrm{Na}$ K ratio values.(Table 1 ). The cleaning of the used syringes and sponges was not very handy, and in some cases four or five through rinses in water were necessary for complete removal of detritus. The borosilicate glasses were used either to collect as to store saliva until its analyses. For a routine collection, the other methods require besides several sponges and syringe the corresponding number of decontaminated flasks to store saliva.

Although a gag was used to keep the lambs' teeth apart during the collections. Nevertheless, in some collections the sponges and tubes were bitten by the molar teeth that in most cases tore into pieces these fragile materials. The thicker plastic tube used along with the vacuum pump resisted the bittings throughout the experiment without any significative damage on its structure.

\section{RESULTS}

The overall volume of saliva collected, in one minute, by different methods of collection is expressed in Table 1. The collection of saliva through sucking with vacuum pump produced significantly larger volume of saliva than sucking with the syringe or with the sponge in both diets. The sodium dietary level did not interfere with the volume of collected saliva.

There was no influence of the method of saliva collection on the values of salivary $\mathrm{Na}: \mathrm{K}$ ratio in both trials. Nevertheless, the lower the sodium dietary level was, the smaller the salivary $\mathrm{Na}: \mathrm{K}$ ratio(Table 1).
Table 1 - Influence of the method of saliva collection and level of dietary sodium on salivary volume/min and $\mathrm{Na} \cdot \mathrm{K}$ ratio.

\begin{tabular}{|c|c|c|c|c|}
\hline \multirow{3}{*}{$\begin{array}{l}\text { Method of } \\
\text { collection }\end{array}$} & \multicolumn{4}{|c|}{ Salivary } \\
\hline & \multicolumn{2}{|c|}{ Volume (ml/min) } & \multicolumn{2}{|c|}{$\mathrm{Na}: \mathrm{K}$ ratio } \\
\hline & NDS & L.DS & NDS & L.DS \\
\hline Swabbing & $0.8+0.3 \mathrm{~h}$ & $0.7 \pm 0.3 b$ & $19.2 \pm 2.9 \mathrm{a}$ & $9.9 \pm 1.7 \mathrm{~b}$ \\
\hline Sucking/Syringe & $0.5 \pm 0.3 b$ & $0.6 \pm 0.2 b$ & $20.6 \pm 2.4 a$ & $10.3 \pm 2.2 \mathrm{~b}$ \\
\hline $\begin{array}{l}\text { Sucking/Vacuum } \\
\text { pump }\end{array}$ & $5.0 \pm 2.6 a$ & $6.3 \pm 2.2 \mathrm{a}$ & $21.4 \pm 2.7 \mathrm{a}$ & $10.9 \pm 2.9 \mathrm{~b}$ \\
\hline
\end{tabular}

\footnotetext{
$a>b(p<0.001)$

NDS = Normal Dietary Sodium

LDS $=$ Low DietarySodium.
}

Ciência Rural, v. 27, n. 2, 1997. 
The salivary $\mathrm{Na}: \mathrm{K}$ ratio values obtained with sheep fed normal or deficient dietary levels of sodium were within the expected range values cited by MORRIS (1980). Five weeks were sufficient time to decrease the salivary $\mathrm{Na}: \mathrm{K}$ ratio values by half. Nevertheless, the lambs did not exhibit any clinical signs of sodium deficiency such as weight loss, pica, anorexia, polydipsia etc (BLOOD et al., 1989). In spite of the narrow salivary $\mathrm{Na}$ : $\mathrm{K}$ ratio detected in the lambs'saliva, these values were not low enough to consider an functional sodium deficiency status but a marginal deficiency. McSWEENEY et al., (1988) induced sodium deficiency in sheep and measured both the salivary $\mathrm{Na}: \mathrm{K}$ ratio and plasma aldosterone concentration. It was concluded, based on the plasma aldosterone concentration, that the ratio of $\mathrm{Na}: \mathrm{K}$ in saliva, when less than 4 is diagnostic of actual $\mathrm{Na}$ deficiency.

In conclusion, the collection of saliva through aspiration with a vacuum pump proved to be very practical, simple, rapid as well as reliable collection method to assess sodium status in sheep.

\section{REFERENCES}

ANDREASI, F,, MENDONÇA, C.X., VEIGA, J.S.M. $\boldsymbol{e}$ t al. Levantamento dos elementos minerais em plantas forrageiras de áreas limitadas do Estado de São Paulo. II Sódio e potássio. Rev Fac Med Vet São Paulo, v. 7, n. 3, p. 605-614, 1966/67.

CAVALHEIRO, A.C.L.; TRINDADE, D.S. Os minerais para bovinos e ovinos criados em pastejo. Porto Alegre: Fund. Banco do Brasil, 1992.142 p

BLOOD, D.C.,; RADOSTITS, O.M. Veterinary medicine. 7. ed. London: Bailliere Tindall, 1989. 1502 p.

DOBSON, A., KAY, N.B.; McDONALD, I. The relation between the composition of parotid saliva and mixed saliva in sheep during the induction of sodium deficiency. Res Vet Sci, v. 1, n. 1 , p. $103-110,1960$.

FIELD, A.C., SUTTLE, N.F., BREBNER, J., et al. An assessment of the efficcacy and safety of selenium and cobalt included in an anthelmintic for sheep. Vet Rec, v. 123, p. 97 -100, 1988.

HOEGGEL, F.V. Free choice mineral supplementation in counteracting the effects of scouring in nematode infected lambs. Edinburgh: 1990, 67 p. Thesis (Tropical animal production and health) - University of Edinburgh, 1990.

McSWEENEY, C.S., CROSS, R.B., WHOLOHAN, B.T., et al. Diagnosis of sodium status in small ruminants. Austr J Agric Res, v. 39 p. 935-942, 1988.

MORIS, J.G. Assessment of sodium requirements of beef cattle: a review. J Ani Sci, v. 50, p. 142-152, 1980.

MURPHY, G.M.; CONNEL, Q.D.A.H. A simple method of collecting saliva to determine the sodium status of cattle and sheep. Austr Vet J, v. 46, n. 12, p. 595-598, 1970.

OOSTERHUIS, C.W.K. Electrolyte, plasma pepsininogen and total $\mathrm{CO}$ changes in lambs with a natural, mixed abomasal and intestinal nematode infection. Edinburgh, 1990, 59 p. Thesis (Tropical animal production and health) - University of Edinburgh, 1991.

ORTOLANI, E.L. Panorama epidemilógico da mortalidade enzoótica de bovinos adultos no Brasil e no Paraguai: retrospectiva e levantamentos. Hora Vet, v. 12, n. 71, p. 2024, 1993. PRADA, F. Estudo da composição de algumas plantas forrageiras oriundas do Mato Grosso do Sul - Sódio e potássio. Rev Fac Med Vet Zoot Univ S Paulo, v. 22, n. 2, p. 141-146, 1985.

SNEDCOR, G.W.; COCKRAN, W.G. Statistical methods. 6. ed. Iowa: State University, 1967. 593 p.

SOUZA, J.C., CONRAD,J.H., MOTT, G.O., et al., Interrelações entre minerais no solo, plantas forrageiras e tecidos animal no norte de Mato Grosso. 4- Zinco, magnésio, sódio e potássio. Pesq Agropec Bras v. 17, p. 11-20, 1982. 